Faculdade de Engenharia de llha Solteira, Universidade Estadual Paulista, Rua Monção, 226, Zona Norte, CEP 15385-000, Ilha Solteira SP, Brazil

${ }^{2}$ Agência Paulista de Tecnologia dos Agronegócios, Regional Alta Paulista, Adamantina, SP Brazil

${ }^{3}$ Faculdade de Ciências Agronômicas, Universidade Estadual Paulista,

Botucatu, SP, Brazil

*autor correspondente

\flaviamariano1@hotmail.com

\title{
Physicochemical characterization of soursop fruits and jellies light and conventional
}

\section{Caracterização físico-química de frutos e geleias light e convencional de graviola}

Flávia Aparecida de Carvalho Mariano-Nasser*, Maurício Dominguez Nasser², Aparecida Conceição Boliani ${ }^{1}$, Eduardo Breno Ribeiro dos Santos ${ }^{1}$, Veridiana Zocoler de Mendonça ${ }^{3}$

\begin{abstract}
Jellies production is one of the ways to add value and increase the soursop fruits use. The aim of the research was to define the physical-chemical characterization of soursop fruit and jellies prepared with sucrose and sweetener. Were prepared two versions of jelly with the pulp of soursop: conventional and light. The conventional jelly was produced with a soursop pulp kilogram, $40 \%$ sucrose, $0.05 \%$ HM pectin and $0.1 \%$ citric acid. The light was produced with a jelly soursop pulp kilogram, $30 \%$ maltitol syrup sweetener (Maltidex ${ }^{\circledR}$ ), $0.05 \%$ LM pectin, $0.0025 \%$ calcium chloride and $0.1 \%$ citric acid. The physico-chemical analyzes in the pulp of soursop in nature and light and conventional jellies were $\mathrm{pH}$, soluble solids ( $\left.{ }^{\circ} \mathrm{Brix}\right)$, titratable acidity ( $\mathrm{g}$ of citric acid $100 \mathrm{~g}^{-1}$ pulp), vitamin $\mathrm{C}$ (mg of ascorbic acid $100 \mathrm{~g}^{-1}$ pulp) and SS / TA ratio. The use of soursop as jelly proved to be a great alternative, because the light and conventional versions developed products showed good chemical features. The sweetener maltitol syrup was efficient for the preparation of the light version, giving body and sweetness to jelly.
\end{abstract}

KEYWORDS: Annona muricata L., processing, sweetener, pectin.
RESUMO: A produção de geleias é uma das formas de agregar valor e aumentar o aproveitamento dos frutos da graviola. O objetivo da pesquisa foi realizar a caracterização físico-química dos frutos de graviola e das geleias elaboradas com sacarose e edulcorante. Foram elaboradas duas versões de geleia com a polpa de graviola: convencional e light. A geleia convencional foi produzida com um quilograma de polpa de graviola, $40 \%$ de sacarose, 0,05\% de pectina HM e 0,1\% de ácido cítrico. A geleia light foi produzida com um quilograma de polpa de graviola, 30\% de edulcorante xarope de Maltitol (Maltidex ${ }^{\circledR}$ ), 0,05\% de pectina LM, $0,0025 \%$ de cloreto de cálcio e $0,1 \%$ de ácido cítrico. As análises físico-químicas realizadas na polpa da graviola in natura e nas geleias light e convencional foram: $\mathrm{pH}$, sólidos solúveis ( ${ }^{\circ} \mathrm{Brix}$ ), acidez titulável ( $\mathrm{g}$ de ácido cítrico $100 \mathrm{~g}^{-1}$ de polpa), vitamina C (mg de ácido ascórbico $100 \mathrm{~g}^{-1}$ de polpa) e relação SS/AT. O aproveitamento da graviola na forma de geleia mostrou-se uma ótima alternativa, pois nas versões light e convencional os produtos desenvolvidos apresentaram boas características químicas. O edulcorante xarope de Maltitol mostrou-se eficiente para a preparação da versão light, dando corpo e dulçor para a geleia.

Palavras-chave: Anona muricata L., processamento, edulcorante, pectina. 


\section{Introduction}

The soursop (Annona muricata L.) belongs to the Annonaceae family and comes with great potential for expansion in Brazil and worldwide, mainly with development studies they can extend the storage time, beneficiation and processing to reach more distant markets of the productive areas (SÃO JOSÉ et al., 2014; BARBOSA; SOARES; CRISÓSTOMO, 2003).

The fruits are classified as climacteric, with fast maturing post-harvest, have acid taste and because of these characteristics most of its production is destined for agribusiness, for the manufacture of ice cream, juices, jellies and sweets (PEREIRA et al., 2011; SACRAMENTO et al., 2003).

Additionally to the use in cooking, the soursop has medicinal potential, evidenced by some research. Torres et al. (2012) in the treatment of pancreatic cancer and Dai et al. (2011) in breast cancer cite the medicinal potential of bioactive of soursop, compounds found in plants and fruits as promising for the control of this disease (PEREIRA et al., 2011).

It is also known that the adoption of fruits and their products in the daily diet is a habit that contributes to improved health, they are important sources of vitamins, minerals and fiber (MELO et al., 2008). The production of jellies adds value to the fruits that were considered unsuitable for fresh consumption, resulting in a sophisticated product of better quality (LOPES, 2007).

Coupled with the growing number of people who have some type of metabolic disorder and need therefore to reduce or abolish the consumption of sugar or only by consumer profile change towards a healthier life, several national and foreign research centers have tried to find sugar substitutes. And this concern also arises in food industries that try to meet the dietary requirements and consumer health (LOBO; SILVA, 2003; MUSSATTO; ROBERTO, 2002).

An alternative is the use of sugar is the maltitol. This is classified as second generation sweetener, and shows sweetness about $80 \%$ to $90 \%$ that of sucrose. It can be used in chocolate preparations, cereal bars, jams, jellies and sorbets (POLINÓIS, 2000).

Therefore, the objective of the research was to study the physicochemical characterization of soursop fruit and jellies made with sucrose and sweetener.

\section{Material and Methods}

For the analysis of soursop and conventional and light jellies development, the fruits were harvested ripe. From a property of Ilha Solteira, the fruits were taken to the laboratory of Food Technology and conducted cleaning and disinfection with sodium hypochlorite $\left(100 \mathrm{mg} \mathrm{L}^{-1}\right)$ for five minutes and rinsed in clean running water.

Then the pectin qualitative test was carried out on pulp to check the content in fruit, was added $5 \mathrm{ml}$ of $95^{\circ} \mathrm{C}$ alcohol to $5 \mathrm{ml}$ of pulp. After stirring the mixture and let at rest for 10 minutes, a precipitate was observed. And, following recommendations of Cruess (1973), the use of pectin in the preparation of jams was needed because there was little precipitate formation.
For the pulping, the fruits were peeled and removed seeds and sieved then separated into portions of one kilogram of pulp for the jams' preparation. The conventional version has been produced with one kilogram of soursop pulp, $40 \%$ sucrose, $0.05 \%$ HM pectin and $0.1 \%$ citric acid. The light jelly was produced with one kilogram of soursop pulp, 30\% sweetener Maltitol syrup (Maltidex ${ }^{\circledR}$ ), $0.05 \%$ pectin LM, $0.0025 \%$ calcium chloride and $0.1 \%$ citric acid.

The jellies components were added in aluminum pans, reserving pectin to the end of the procedure. Proceeded to cooking, with manual stirring, and by the ending time of cooking was added pectin and manually stirring continued until the formation of the jelly consistency. The time spent on preparing each jelly was 20 to 30 minutes. After this step, the hot jellies were packaged in glass containers with a capacity of $250 \mathrm{~g}$, previously sterilized at $121{ }^{\circ} \mathrm{C}$ for 15 minutes and closed with metal lid, and were immediately sealed, labeled and stored at atmospheric temperature.

The soursop pulp was analyzed for $\mathrm{pH}$, soluble solids ( ${ }^{\circ}$ Brix), titratable acidity ( $\mathrm{g}$ citric acid $100 \mathrm{~g}^{-1}$ pulp), vitamin C (mg ascorbic acid $100 \mathrm{~g}^{-1}$ pulp) and SS/TA ratio. For jellies were analyzed $\mathrm{pH}$, titratable acidity, soluble solids and vitamin $\mathrm{C}$ (NSTITUTO..., 2008).

The calculation of mean and standard deviation of chemical analysis was carried out using the Excel software (Microsoft ${ }^{\circledR}$ Excel, SR-2, Redmond, WA, USA).

\section{Results and Discussion}

In the characterization of raw fruits (Table 1), it is observed $\mathrm{pH} 3.53 \pm 0.1$. Different values were found by Sacramento et al. (2003) that working with three types of soursop Lisa, Morada and Comum found a pH range between 3.44 and 3.47. And Canuto et al. (2010) when they worked with the characterization of fruits of the Amazon, found in $\mathrm{pH}$ soursop amounting to $3.7 \pm 0.1$. These differences in $\mathrm{pH}$ values probably occurred due to different climatic and soil conditions in the regions where the fruit was grown. Batista et al. (2014), they point out that consumers of fresh fruits prefer less acidic $\mathrm{pH}$, thus explaining why much of the soursop production is for the industry.

It is noteworthy that an acidic $\mathrm{pH}$ promotes the conservation and as are desired by the agricultural industry result in lower production costs by reducing the acid addition to the pulp. According Hoffmann (2001), the food industry employs the $\mathrm{pH}$

Table 1. Physicochemical characterization of the soursop fruit.

\begin{tabular}{cc}
\hline Physicochemical analysis & Soursop pulp \\
\hline pH & $3.53 \pm 0.01$ \\
Soluble Solids & $8.4 \pm 0.1$ \\
Titratable Acidity & $0.99 \pm \mathbf{0 . 0 2}$ \\
Vitamin C & $25.02 \pm 0.41$ \\
SS/AT & $\mathbf{8 . 5 0} \pm \mathbf{0 . 0 5}$
\end{tabular}

Average of 03 analytical replicates \pm standard deviation. Soluble Solids ( ${ }^{\circ}$ Brix $)$; Titratable Acidity ( $\mathrm{g}$ of citric acid $100 \mathrm{~g}^{-1}$ pulp), Vitamin C (mg of ascorbic acid $100 \mathrm{~g}^{-1}$ pulp). 
effect on the microorganisms for the preservation of products, and the $\mathrm{pH} \leq 4.5$ does not happen Clostridium botulinum development as well as pathogenic bacteria

For the soluble solids content was $8.4 \pm 0.1^{\circ}$ Brix in fruits in nature. Values greater than the work were cited in soursop fruit in literature, Mata et al. (2005) $10.7^{\circ}$ Brix, Sacramento et al. (2003), $13.85{ }^{\circ}$ Brix, Canuto et al. (2010), $12.0{ }^{\circ}$ Brix and Andrade et al. (2011) $11.4^{\circ} \mathrm{Brix}$. The difference in levels may be related to the degree of ripeness of fruit studied and the variety used and the conditions of cultivation.

Mean titratable acidity was $0.99 \pm 0.02 \mathrm{~g}$ of citric acid $100 \mathrm{~g}^{-1}$ pulp. Similar results were cited by Andrade et al. (2011) and Orsi et al. (2012), which working with fruits soursop found acidity content of $1.03 \mathrm{~g}$ of citric acid 100-1 pulp and $0.91 \mathrm{~g} \pm 0.1 \mathrm{~g}$ of citric acid $100 \mathrm{~g}^{-1}$ pulp.

The vitamin C content of soursop fruits were $25.02 \pm 0.41 \mathrm{mg}$ ascorbic acid $100 \mathrm{~g}^{-1}$ pulp. Agreeing with the findings by Mata et al. (2005) observed that about $25.3 \mathrm{mg}$ of ascorbic acid 100-1g pulp in fruits of soursop. The work values were higher than those found by Andrade et al. (2011), about $17.93 \mathrm{mg}$ of ascorbic acid 100-1g of pulp on average, and inferior to that obtained by Sacramento et al. (2003) who found in his research a value ranging from 35.60 to $38.5 \mathrm{mg}$ of ascorbic acid $100 \mathrm{~g}^{-1}$ pulp. The SS / TA ratio found in the study was $8.5 \pm 0.05$. Agreeing with Mata et al. (2005) reported value of 8.9.

Following recommendation of identity and minimum quality standards (IQS) for pulp established by the Ministry of Agriculture, the soursop pulp composition should display the following minimum values: soluble solids $9{ }^{\circ} \mathrm{Brix}$; $\mathrm{pH} 3.50$; titratable acidity in citric acid $0.60 \mathrm{~g} / 100 \mathrm{~g}$; ascorbic acid $10 \mathrm{mg} / 100 \mathrm{~g}$; and total solids $13,0 \mathrm{~g} / 100 \mathrm{~g}$. Comparing the minimum values of the standards with the results of Table 1, it can be seen that only the soluble solids were below the minimum rates of PIQ the Ministry of Agriculture (BRASIL, 2000).

In Table 2 we observe the physico-chemical analysis of the two versions of soursop jam. The $\mathrm{pH}$ of the conventional jelly and light were $3.3 \pm 0.04$ and $3.3 \pm 0.05$, respectively. In relation to the pulp, the $\mathrm{pH}$ for jellies became more acids, probably by adding citric acid in the formulation. This $\mathrm{pH}$ reached is ideal for jellies, because according to this Lago, Gomes and Silva (2006) as the $\mathrm{pH}$ of jellies, suggested maximum $\mathrm{pH}$ of 3.4, and below 3.0 can occur syneresis. The same happened with Orsi et al. (2012) that working with soursop jelly processed with sucrose found $\mathrm{pH}$ of $3.41 \pm 0.01$. Superior results were

Table 2. Physicochemical characteristics of conventional and light soursop jelly.

\begin{tabular}{ccc}
\hline \multirow{2}{*}{ Physicochemical analysis } & \multicolumn{2}{c}{ Soursop jelly } \\
\cline { 2 - 3 } & Conventional & Light \\
\hline pH & $3.3 \pm 0.04$ & $3.3 \pm 0.05$ \\
Soluble Solids & $61.8 \pm 0.76$ & $49.77 \pm 0.68$ \\
Titratable Acidity & $1.4 \pm 0.02$ & $1.52 \pm 0.06$ \\
Vitamin C & $20.3 \pm 1.58$ & $\mathbf{2 1 . 4 8} \pm \mathbf{1 . 1 5}$ \\
\hline
\end{tabular}

Average of 03 analytical replicates \pm standard deviation. Soluble Solids ( $\left.{ }^{\circ} \mathrm{Brix}\right)$; Titratable Acidity ( $\mathrm{g}$ of citric acid $100 \mathrm{~g}^{-1}$ pulp), Vitamin C (mg of ascorbic acid $100 \mathrm{~g}^{-1}$ pulp). described by Mota (2006) in conventional jellies blackberry and Lago, Gomes and Silva (2006), jelly jambolan, the authors obtained pH 3.57 and 3.41, respectively. In relation to light jelly, similar results were found in dietary jellies of blackberry by Mota (2007), 3.37, and higher by Lago-Vanzela et al. (2011), from 3.68 to 3.72 .

The soluble solids of jellies increased relative to the pulp after processing, conventional $61.8 \pm 0.76$ and a light version $49.77 \pm 0.68$. Probably due to cooking, which causes reduction of humidity and the addition of sucrose and sweetener during processing. The values of soluble solids are in accordance with the standards required in Resolution No. 272 (BRASIL, 2005). Superior results to the work were found in conventional jelly by Orsi et al. (2012) in jellies soursop, $68.6 \pm 0,01^{\circ}$ Brix and Lago et al. (2006), jelly jambolan, $67^{\circ}$ Brix. In relation to light jelly, the results agree with the levels found in pineapple jelly light by Granada et al. (2005), $46^{\circ}$ Brix. However LagoVanzela et al. (2011) in light jellies jambolan found soluble solids content of $55^{\circ}$ Brix, higher than that found in the assay.

For the titratable acidity of the conventional jelly strength was $1.4 \pm 0.02 \mathrm{~g}$ of citric acid $100 \mathrm{~g}^{-1}$ pulp and the light jelly $1.52 \pm 0.06$, the two versions became more acidic that pulp. The same happened with Mota (2007) in dietary jellies of blackberry, who observed higher acidity jelly with sweeteners compared to conventional. Lower levels of acidity were cited by Lago-Vanzela et al. (2011) in research with jellies light of jambolan (0.98 to $1.09 \mathrm{~g}$ of citric acid 100-1 pulp) and Granada et al. (2005) in light pineapple jelly (0.85 to $0.95 \mathrm{~g}$ citric acid $100 \mathrm{~g}^{-1}$ pulp).

For vitamin $\mathrm{C}$ content, in the conventional jelly was $20.3 \pm 1.58 \mathrm{mg}$ ascorbic acid $100 \mathrm{~g}^{-1}$ pulp and light version of the jelly $21.48 \pm 1.15 \mathrm{mg}$ ascorbic acid 100-1g pulp. The content of vitamin $\mathrm{C}$ decreased in comparison to the fruit pulp in nature, probably due to cooking jelly. This compound is broken down easily in heat presence (VILAS-BOAS, 1999). The same happened with Maciel et al. (2009) working with acerola, mango and mixed jellies; Caetano, Daiuto and Vieites (2012) in acerola jelly, Mélo, Lima and Nascimento (1999) in acerola and surinam cherry jelly, all authors observed reduction in vitamin $\mathrm{C}$ content after making jelly.

\section{Conclusion}

The use of soursop as conventional jelly and light proved viable for fruit that would have commercial value selling in nature, adding value to the product.

Processing of light soursop jelly appears as a product alternative with reduced sugar. The use of maltitol syrup sweetener was efficient for the preparation of light version, giving sweetness and body to jelly.

\section{Acknowledgements}

At Cargill company for supplying the sweetener by donation. 


\section{References}

ANDRADE, M. R. L. et al. Caracterização físico-química do fruto graviola (Annona muricata L.) comercializada em Teresina-PI. In: REUNIÃO ANUAL DA SOCIEDADE BRASILEIRA PARA O PROGRESSO DA CIÊNCIA, 63., 2011, Goiânia. Anais... Goiânia: SBPC, 2011. Available from: <http://www.sbpcnet.org.br/livro/63ra/ resumos/resumos/2261.htm>. Access in: 24 Nov. 2012.

BARBOSA, Z.; SOARES, I.; CRISÓSTOMO, L. A. Crescimento e absorção de nutrientes por mudas de graviola. Revista Brasileira de Fruticultura, Jaboticabal, v. 25, n. 3, p. 519-522, 2003. http:// dx.doi.org/10.1590/S0100-29452003000300039.

BATISTA, A. D. et al. Caracterização física, físico-química e química de frutos de pitangueiras oriundas de Cinco Municípios Baianos. Revista Magistra Cruz das Almas, Cruz das Almas, v. 26, n. 3, p. 397-407, 2014.

BRASIL. Ministério da Agricultura e do Abastecimento. Instrução Normativa $\mathrm{n}^{\circ} 01$, de 07 de janeiro de 2000. Aprova o Regulamento Técnico Geral para fixação dos Padrões de Identidade e Qualidade para Polpa de Fruta. Diário Oficial da República Federativa do Brasil, Brasília, DF, 10 Jan. 2000. Seção 1. p.54.

BRASIL. Agência Nacional de Vigilância Sanitária - ANVISA. Resolução n ${ }^{\circ} 272$, de 23 de setembro de 2005. Aprova o "Regulamento Técnico para Produtos de Vegetais, Produtos de Frutas e Cogumelos Comestíveis". Diário Oficial da República Federativa do Brasil, Brasília, DF, 23 Sept. 2005. Available from: <http://portal.anvisa. gov.br/wps/wcm/connect/ac09380047457ea18a84de3fbc4c6735/ RDC_272_2005.pdf?MOD=AJPERES $>$. Access in: 05 June 2015.

CAETANO, P. K.; DAIUTO, E. R.; VIEITES, R. L. Característica físico-química e sensorial de geleia elaborada com polpa e suco de acerola. Brazilian Journal Food Technology, Campinas, v. 15 , n. 3, p. 191-197, 2012. http://dx.doi.org/10.1590/S198167232012005000011 .

CANUTO, G. A. B. et al. Caracterização físico-química de polpas de frutos da Amazônia e sua correlação com a atividade anti-radical livre. Revista Brasileira de Fruticultura, Jaboticabal, v. 32, n. 4, p. 11961205, 2010. http://dx.doi.org/10.1590/S0100-29452010005000122.

CRUESS, W. V. Produtos industriais de frutas e hortaliças. São Paulo: Edgar Blücher, 1973. 446 p. v. 1.

DAI, Y. et al. Selective growth inhibition of human breast cancer cells by graviola fruit extract in vitro and in vivo involving downregulation of EGFR expression. Nutrition and Cancer, Philadelphia, v. 63, n. 5, p. 795-801, 2011. http://dx.doi.org/10.1080/01635581.2011. 563027. PMid:21767082.

GRANADA, G. G. et al. Caracterização física, química, microbiológica e sensorial de geleias light de abacaxi. Ciência e Tecnologia de Alimentos, Campinas, v. 25, n. 4, p. 629-635, 2005. http://dx.doi. org/10.1590/S0101-20612005000400002.

HOFFMANN, F. L. Fatores limitantes à proliferação de microorganismos em alimentos. Brasil Alimentos, São Paulo, v. 9, n. 1, p. 23-30, 2001.

INSTITUTO ADOLFO LUTZ. Métodos físico-químicos para análise de alimentos. 4th ed. São Paulo: Instituto Adolfo Lutz, 2008. 1020 p. Available from: < http://www.crq4.org.br/sms/files/ file/analisedealimentosial_2008.pdf $>$. Access in: 19 Mar. 2015.

LAGO, E. S.; GOMES, E.; SILVA, R. Produção de geleia de jambolão (Syzygium cumini lamarck): processamento, parâmetros físico-químicos e avaliação sensorial. Ciência e Tecnologia de
Alimentos, Campinas, v. 26, n. 4, p. 847-852, 2006. http://dx.doi. org/10.1590/S0101-20612006000400021.

LAGO-VANZELA, E. S. et al. Physical-chemical, caloric and sensory characterization of light jambolan (Syzygium cumini Lamarck) jelly. Ciência e Tecnologia Alimentos, Campinas, v. 31, n. 3, p. 666-673, 2011. http://dx.doi.org/10.1590/S0101-20612011000300018.

LOBO, A. R.; SILVA, G. M. L. Aspectos tecnológicos de produtos de panificação e massas alimentícias com teor calórico reduzido. Boletim SBCTA, Campinas, v. 37, n. 1, p. 1-8, 2003.

LOPES, R. L. T. Dossiê técnico: fabricação de geléias. CETEC; SBRT, 2007. Available from:<http://www.sbrt.ibict.br/dossie-tecnico/ downloadsDT/ODc $=>$. Access in: 03 June 2015.

MACIEL, M. I. S. et al. Características sensoriais e físico-químicas de geleias mistas de manga e acerola. Boletim CEPPA, Curitiba, v. 27, n. 2, p. 247-256, 2009.

MATA, M. E. M. R. C. et al. Obtenção de graviola em pó pelo processo de liofilização. Revista Brasileira de Produtos Agroindustriais, Campina Grande, v. 7, n. 2, p. 165-172, 2005. Especial.

MELO, E. A. et al. Teor de fenólicos totais e capacidade antioxidante de polpas congeladas de frutas. Alimentos e Nutrição, Araraquara, v. 19, n. 1, p. 67-72, 2008.

MÉLO, E. A.; LIMA, V. L. A. G.; NASCIMENTO, P. P. Formulação e avaliação físico-química e sensorial de geleia mista de pitanga (Eugenia uniflora L.) e acerola (Malpighia sp.). Boletim CEPPA, Curitiba, v. 17, n. 1, p. 33-44, 1999.

MOTA, R. V. Caracterização física e química de geleia de amora-preta. Ciência e Tecnologia de Alimentos, Campinas, v. 26, n. 3, p. 539543, 2006. http://dx.doi.org/10.1590/S0101-20612006000300009.

MOTA, R. V. Características químicas e aceitabilidade de geleias de amora-preta de baixo teor de sólidos solúveis. Brazilian Journal of Food Technology, Campinas, v. 10, n. 2, p. 116-121, 2007.

MUSSATTO, S. I.; ROBERTO, I. C. Xilitol: edulcorante com efeitos benéficos para a saúde humana. Revista Brasileira de Ciências Farmacêuticas, São Paulo, v. 38, n. 4, p. 401-413, 2002. http:// dx.doi.org/10.1590/S1516-93322002000400003.

ORSI, D. C. et al. Use of sugar apple, atemoya and soursop for technological development of jams: chemical and sensorial composition. Ciência e Agrotecnologia, Lavras, v. 36, n. 5, 2012.

PEREIRA, M. C. T. et al. Anonáceas: pinha, atemóia e graviola. Informe Agropecuário, Belo Horizonte, v. 32, n. 264, p. 26-34, 2011.

POLINÓIS. Revista Aditivos \& Ingredientes, São Paulo, n. 8, p. 36-41, 2000.

SACRAMENTO, C. K. et al. Caracterização física e química de frutos de três tipos de gravioleira (Annona muricata L.). Revista Brasileira Fruticultura, Jaboticabal, v. 25, n. 2, p. 329-331, 2003. http://dx.doi.org/10.1590/S0100-29452003000200037.

SÃO JOSÉ, A. R. et al. Atualidades e perspectivas das Anonáceas no mundo. Revista Brasileira de Fruticultura, Cruz Das Almas, v. 36, n. 1, p. 86-93, 2014. Especial.

TORRES, M. P. et al. Graviola: a novel promising natural-derived drug that inhibits tumorigenicity and metastasis of pancreatic cancer cells in vitro and in vivo through altering cell metabolism. Cancer Letters, Amsterdam, v. 323, n. 1, p. 29-40, 2012. http://dx.doi. org/10.1016/j.canlet.2012.03.031. PMid:22475682.

VILAS-BOAS, E. V. B. Alimentos e nutrientes. Lavras: UFLA; FAEPE, 1999. 74 p. 